\title{
BILAYER TABLET TENDERED IMMEDIATE RELEASE OF PARACETAMOL AND SUSTAINED RELEASE OF IBUPROFEN FOR QUICK ONSET OF ACTION AGAINST PAIN AND FEVER
}

\author{
DEVENDER CHAUHAN*, DINESH KAUSHIK \\ Department of Hindu College of Pharmacy, Sonipat, Haryana, India. Email: devenderchauhan1112@gmail.com
}

Received: 15 September 2019, Revised and Accepted: 17 October 2019

\begin{abstract}
Objective: The objective of this research was to formulate bi-layer tablet which contains immediate-release layer of Paracetamol for quick onset of action and sustained release of Ibuprofen for prolonging long period.

Materials and Methods: The following chemicals were used: Paracetamol (Combiotic Global Pvt. Ltd., India), Ibuprofen (Combiotic Global Pvt. Ltd., India), microcrystalline cellulose (MCC) (Avicel), and Polyvinylpyrrolidone (PVP) K-30 (Loba Chem). Wet granulation method was adapted to formulate the bilayer tablets. The immediate-release layer of Paracetamol was prepared using sodium starch glycolate as superdisintegrants, MCC as diluent, starch as binder. The sustained release layer of Ibuprofen was prepared using high-performance liquid chromatography E50LV and ethyl cellulose as binder along with other excipients such as MCC, PVP, and magnesium stearate by wet granulation technique.
\end{abstract}

Result and Discussion: The release rate of Paracetamol from Formulations 1 was more than $80 \%$ at 40 min. In case of Ibuprofen, sustained-release polymers such as HPMC E50 LV were used to increase the release time.

Conclusion: The bilayer tablets were prepared and show good release rate.

Keywords: Paracetamol, Ibuprofen, Analgesic, Immediate release, Sustained release, High-performance liquid chromatography.

(C) 2019 The Authors. Published by Innovare Academic Sciences Pvt Ltd. This is an open access article under the CC BY license (http://creativecommons. org/licenses/by/4. 0/) DOI: http://dx.doi.org/10.22159/ajpcr.2019.v12i11.35690

\section{INTRODUCTION}

Oral drug delivery system is considered to be one of the most convenient and commonly employed drug delivery system as it possesses some specific advantageous characteristics, such as ease of administration [1,2]. The modified release products are usually designed to provide slow and continuous delivery of drug over the entire dosing interval and improve patient compliance and convenience [3,4]. In formulation of oral controlled release formulation, hydrophilic polymers are most frequently used as polymeric retardant materials due to their ease of manufacturing, relatively low cost, favorable in vivo performance, and versatility in controlling the release of drug with wide range of physicochemical properties [5-7].

Bi-layer tablet is a new era for successful development of controlled release formulation along with various features to provide successful drug delivery $[8,9]$. Bi-layer tablets can be primary option to avoid chemical incompatibilities between APIs by physical separation and to enable the development of different drug release profiles. Bi-layer tablets are novel drug delivery systems where a combination of two or more drugs in a single unit $[10,11]$. Bi-layer tablet is suitable for sequential release of two drugs in combination in which one layer is for immediate release and second layer is sustained release. Hence, the use of bi-layer tablets is a very different aspect for anti-inflammatory, analgesic, diabetic, and anti-hypertensive drugs where combination therapy is often used $[12,13]$.

\section{MATERIALS AND METHODS}

\section{Materials}

The following chemicals were used: Paracetamol (Combiotic Global Pvt. Ltd., India), Ibuprofen (Combiotic Global Pvt. Ltd., India), Microcrystalline cellulose (MCC) (Avicel), Polyvinylpyrrolidone (PVP) K-30, starch, sodium starch glycolate, IPA, HPMC, Ethanol and Ethyl cellulose (Loba Chemie), Acetonitrile (High-performance liquid chromatography [HPLC] grade), and Methanol (HPLC grade) (Merck).
Methods

Solubility study

The solubility study of drugs was performed in water, methanol, ethanol, acetone, $0.1 \mathrm{~N} \mathrm{HCl}$, phosphate buffer $\mathrm{pH} 6.8$, phosphate buffer $\mathrm{pH} 7.4$, and individually by keeping the drug-containing test tube on vortex mixture.

Determination of melting point

All dynamic differential scanning calorimetry (DSC) studies of pure drugs were carried out on DSCTA 60 Shimadzu Thermal Analyzer. The instrument was calibrated using high purity indium metal as standard. The scans were taken in nitrogen atmosphere at the heating rate of $10^{\circ} \mathrm{C} / \mathrm{min}$.

\section{Linearity and validation by HPLC method}

Mobile phase preparation

A mixture of 75 volume of a buffer solution prepared by dissolving $3.9 \mathrm{~g}$ of sodium dihydrogen phosphate dihydrate and $8.9 \mathrm{~g}$ disodium hydrogen phosphate dihydrate in water, adjust to $\mathrm{pH} 7.0$ with orthophosphoric acid, dilute to $1000 \mathrm{ml}$ with water and 24.5 volume of acetonitrile and 0.5 volume of methanol.

\section{Chromatic condition \\ Apparatus: HPLC \\ Column: C8 \\ Wave length: $220 \mathrm{~nm}$ \\ Injection volume: $20 \mu \mathrm{l}$ \\ Flow rate: $1 \mathrm{ml} / \mathrm{min}$ \\ Column temperature: $35^{\circ} \mathrm{C}$ \\ Type of detector: UV}

\section{- $\quad$ Standard stock solution of Paracetamo}

Accurately weighed $100 \mathrm{mg}$ of Paracetamol and was dissolved in $100 \mathrm{ml}$ of the mobile phase. $1 \mathrm{ml}$ pipette out from above solution and taken in $10 \mathrm{ml}$ volumetric flask and volume make up with mobile phase. A standard stock solution contains $100 \mu \mathrm{g} / \mathrm{ml}$. 
Standard graph of Paracetamol: Form this standard stock solution, a series of dilution $(10,20,30,40$, and $50 \mu \mathrm{g} / \mathrm{ml})$ were prepared using mobile phase.

- Standard stock solution of Ibuprofen

Accurately weighed $100 \mathrm{mg}$ of Ibuprofen and was dissolved in $100 \mathrm{ml}$ of mobile phase. $1 \mathrm{ml}$ pipette out from above solution and taken

Table 1: Formulations containing Paracetamol immediaterelease layer (in mgs)

\begin{tabular}{llllll}
\hline Ingredients (mg) & F1 & F2 & F3 & F4 & F5 \\
\hline Paracetamol & 325 & 325 & 325 & 325 & 325 \\
MCC & 48 & 48 & 48 & 48 & 48 \\
Starch & 32 & 64 & - & - & 48 \\
PVP K-30 & - & - & 6 & 12 & 32 \\
Sodium starch glycolate & 7 & 7 & 7 & 7 & 7 \\
Isopropyl alcohol & q.s & q.s & q.s & q.s & q.s \\
\hline
\end{tabular}

MCC: Microcrystalline cellulose

Table 2: Formulations containing Ibuprofen release layer (in mgs)

\begin{tabular}{llllll}
\hline Ingredients (mg) & F1 & F2 & F3 & F4 & F5 \\
\hline Ibuprofen & 400 & 400 & 400 & 400 & 400 \\
MCC & 40 & 40 & 40 & 40 & 40 \\
HPMC E50LV & 80 & 120 & - & - & 80 \\
Ethylcellulose & - & - & 30 & 60 & 30 \\
PVP K-30 & 8 & 8 & 8 & 8 & 8 \\
Magnesium stearate & 5 & 5 & 5 & 5 & 5 \\
Talc & 5 & 5 & 5 & 5 & 5 \\
Isopropyl alcohol & q.s & q.s & q.s & q.s & q.s \\
Erytrosine & q.s & q.s & q.s & q.s & q.s \\
\hline
\end{tabular}

Table 3: Comparison between peaks obtained in drug and in mixture

\begin{tabular}{lll}
\hline $\begin{array}{l}\text { Peak obtained in } \\
\text { drug } \\
\text { (frequency } \mathbf{~ c m}^{-1} \text { ) }\end{array}$ & Description & $\begin{array}{l}\text { Peak obtained } \\
\text { in mixture } \\
\text { (frequency } \mathbf{c m}^{-\mathbf{1}} \text { ) }\end{array}$ \\
\hline 3628 & OH group & 3633 \\
3441 & NH group & 3451 \\
2981,2890 & C-H stretch of $\mathrm{CH}_{3}, \mathrm{CH}_{2}$ & 2991,2841 \\
1338 & C-H bending of $\mathrm{CH}_{2}$ & 1310 \\
1645 & C=O stretch of $\mathrm{amide}^{2}$ & 1648 \\
\hline
\end{tabular}

Table 4: Area of different dilutions of Paracetamol

\begin{tabular}{lll}
\hline S. No. & Concentration $(\boldsymbol{\mu g} / \mathbf{m l})$ & Peak area \\
\hline 1. & 0 & 0 \\
2. & 10 & 774,357 \\
3. & 20 & 779,816 \\
4. & 30 & 785,925 \\
5. & 40 & 791,342 \\
6. & 50 & 796,598 \\
\hline
\end{tabular}

in $10 \mathrm{ml}$ volumetric flask and volume make up with mobile phase. A standard stock solution contains $100 \mu \mathrm{g} / \mathrm{ml}$.

Standard graph of Ibuprofen: Form this standard stock solution, a series of dilution $(10,20,30,40$, and $50 \mu \mathrm{g} / \mathrm{ml})$ were prepared using the mobile phase [21].

\section{Fourier transform infrared spectroscopy (FTIR)}

The selected drug and polymers were characterized by FT-IR spectroscopy and the FTIR spectra of the pure drug Paracetamol with used excipients such as MCC, PVP K-30, starch, and sodium starch glycolate and Ibuprofen with excipients such as HPMC E50LV, ethylcellulose, PVP K-30, magnesium stearate, and talc were recorded to know the drug excipient interactions. The spectrum was recorded for pure drug, physical mixture of combination of all the excipients and drugs. The scanning range was $4000-500 \mathrm{~cm}^{-1}$ [15].

\section{Formulation of bilayer tablets}

The proposed bilayer tablets contain two layers.

1. An immediate release layer containing Paracetamol.

2. Sustained-release layer containing Ibuprofen.

\section{Formulation of Paracetamol granules}

Different formulations of immediate-release tablets of the Paracetamol layer (F1-F5) were prepared by wet granulation method using different excipients such as MCC, starch, and PVP K-30 as a binder and sodium starch glycolate were used as disintegrants.

Procedure

Appropriate quantities of Paracetamol and excipients such as MCC, Starch, PVP K-30, and sodium starch glycolate were measured accurately, and all the measured powders were sifted through Sieve no \# 40. The above-sifted materials were mixed rapidly for $5 \mathrm{~min}$ and again passed through sieve no 40. Isopropyl alcohol having (2\%) w/v amount of starch and PVP K-30 was used as the granulating solution and the solution was added to the mixture in step 2 and was kneaded for 2-5 min, then the kneaded mass was passed through sieve no \# 16 to obtain the granules. The granules obtained in step 3 were dried in a tray drier at $50^{\circ} \mathrm{C}$ for $2 \mathrm{~h}$. The dried granules were lubricated uniformly with weighed quantities of magnesium stearate. The above granules were compressed into tablets by CADMACH multi-station tablet compression machine using $19.1 \times 8.75 \mathrm{~mm}$ punch.

\section{Formulation of Ibuprofen granules}

Different formulations of sustained-release tablets of Ibuprofen layer (F1-F5) were prepared by wet granulation method using different excipients such as MCC, HPMC E50 LV, and ethyl cellulose used as sustained release polymer, PVP $\mathrm{K}-30$ as a binder, and magnesium stearate as a lubricant.

\section{Procedure}

Appropriate quantities of Ibuprofen and excipients such as MCC, HPMC E50 LV, and Ethyl Cellulose were measured accurately, and all the measured powders were sifted through Sieve no \# 40. The above-sifted materials were mixed rapidly for $5 \mathrm{~min}$ and again passed through sieve no 40. Isopropyl alcohol having $2 \% \mathrm{w} / \mathrm{v}$ amount of PVP K-30 was used

Table 5: Pre-compression parameters of Paracetamol granules

\begin{tabular}{|c|c|c|c|c|c|}
\hline Formulation code & $\begin{array}{l}\text { Angle of repose } \\
(\theta)( \pm S D)\end{array}$ & $\begin{array}{l}\text { Bulk density } \\
(\mathrm{g} / \mathrm{cc})( \pm \mathrm{SD})\end{array}$ & $\begin{array}{l}\text { Tapped density } \\
(\mathrm{g} / \mathrm{cc})( \pm \mathrm{SD})\end{array}$ & $\begin{array}{l}\text { Carr's index }(\%) \\
( \pm \text { SD) }\end{array}$ & $\begin{array}{l}\text { Hausner's ratio } \\
( \pm S D)\end{array}$ \\
\hline F1 & $25.5 \pm 0.31$ & $0.735 \pm 0.12$ & $0.836 \pm 0.08$ & $14.52 \pm 0.06$ & $1.13 \pm 0.09$ \\
\hline $\mathrm{F} 2$ & $25.1 \pm 0.45$ & $0.781 \pm 0.09$ & $0.899 \pm 0.09$ & $15.10 \pm 0.05$ & $1.15 \pm 0.07$ \\
\hline F3 & $26.3 \pm 0.98$ & $0.782 \pm 0.08$ & $0.902 \pm 0.08$ & $15.34 \pm 0.08$ & $1.15 \pm 0.09$ \\
\hline F4 & $28.4 \pm 1.24$ & $0.781 \pm 0.12$ & $0.895 \pm 0.09$ & $14.59 \pm 0.05$ & $1.14 \pm 0.05$ \\
\hline F5 & $28.6 \pm 0.88$ & $0.751 \pm 0.17$ & $0.845 \pm 0.16$ & $14.58 \pm 0.05$ & $1.12 \pm 0.07$ \\
\hline
\end{tabular}

(S.D=Standard deviation), $\mathrm{n}=3$ 
as the granulating solution and the solution was added to the mixture in step 2 and was kneaded for 2-5 min, then the kneaded mass was passed through sieve no \# 16 to obtain the granules. The granules obtained in step 3 were dried in a tray drier at $50^{\circ} \mathrm{C}$ for $2 \mathrm{~h}$. The dried granules were lubricated uniformly with weighed quantities of magnesium stearate. The above granules were compressed into tablets by CADMACH multi-station tablet compression machine using $19.1 \times$ $18.75 \mathrm{~mm}$ punch.

\section{Evaluation of granules}

\section{Angle of repose $(\theta)$}

Angle of repose is an indication of fractional forces existing between granules particles. The maximum angle possible between the surface of the pile of granules and the horizontal plane gives the angle of repose.

$$
\tan (q)=\frac{h}{r}
$$

Where $(\theta)=$ angle of repose

$\mathrm{h}=$ height of heap of granules

$\mathrm{r}=$ radius of heap

\section{Bulk density}

Bulk density of the powder is the ratio of the mass of an untapped powder sample and its volume indicating the contribution of the intraparticulate void volume. The bulk density is expressed in grams per $\mathrm{ml}(\mathrm{g} / \mathrm{ml})$. Bulk density is determined by weighing powder into a dry graduated $250 \mathrm{ml}$ cylinder. The powder was carefully leveled without compacting, volume $\left(V_{0}\right)$ was recorded, and bulk density $\mathrm{g} / \mathrm{ml}$ was calculated using the following formula.

$$
\text { Bulk density }=\frac{\text { Mass of theBlend powder }}{\text { Volumeoccupied by thepowderblend }}
$$

\section{Tapped density}

Tapped density is obtained by mechanically tapping a graduated measuring cylinder or vessel containing a powder sample. After observing the initial powder volume to weight, the measuring cylinder or vessel is mechanically tapped, and volume readings are taken until little less than $1 \%$ further volume change is observed. The mechanical tapping is achieved by raising the cylinder or vessel and allowing it to drop under its own weight at specified distance. Secure the cylinder in the holder of the apparatus with weighed powder sample. Measure 100-200 taps and observe the corresponding volumes to the nearest graduated unit [16].

Table 6: Area of different dilutions of Ibuprofen

\begin{tabular}{lll}
\hline S. No. & Concentration $(\boldsymbol{\mu g} / \mathbf{m l})$ & Peak area \\
\hline 1. & 10 & $1,291,267$ \\
2. & 20 & $1,367,245$ \\
3. & 30 & $1,459,834$ \\
4. & 40 & $1,524,783$ \\
5. & 50 & $1,592,643$ \\
\hline
\end{tabular}

Tapped density $=\frac{\text { Mass of thepowder Blend taken }}{\text { Tapped Volumeof thepowderblend }}$

Carr's index

The Carr's Index and Hausner's ratio are measures of the porosity of a powder to be compressed. They measure the relative importance of interparticle interactions. For poor flow materials, there are frequently greater interparticulate interactions and a greater difference between the bulk and tapped densities. These differences are reflected in the compressibility index and Hausner's Ratio. Carr's index was calculated using the following formula.

$$
\text { Carr's Index }=\frac{\text { TD }- \text { BD }}{\text { TD }} \cdot 100
$$

Hausner's ratio

The Hausner's ratio is a number that is correlated to the flowability of a powder or granular material. Hausner's ratio is calculated using the following formula [17]:

$$
\text { Hausner's ratio }=\frac{\mathrm{TD}}{\mathrm{BD}}
$$

\section{Evaluation of tablets}

The formulation tablets were evaluated for the following physical parameters.

\section{Thickness}

Thickness depends on the die filling, physical properties of the material to be compared. It is possible of small variation in the thickness of individual tablets in a batch. However, it should not appear to the unaided eye. The thickness and diameter can be measured by Vernier caliper [18].

\section{Weight variation test}

Twenty tablets were selected randomly and weighed individually. Calculate average weight compare the individual tablet weight to the average. Not more than two of the individual weights derivate from the average weight by more than percentage is shown in tablet and none derivate by more than twice the percentage.

\section{Hardness}

Tablets must possess sufficient strength or hardness and can be measured by Monsanto Hardness Tester. Ten tablets were randomly picked from each formulation and were evaluated for hardness and can be expressed in $\mathrm{kg} / \mathrm{cm}^{2}$.

\section{Friability}

Friability can be performed in Roche friabilator; preweighed ten tablets were introduced in the friabilator. Then, the machine was operated for 100 revolutions. Tablets were dropped from a distance of 6 in each revolution. Tablets were then dusted and reweighed. Loss of $<1 \%$ in

\begin{tabular}{|c|c|c|c|c|c|}
\hline Formulation Code & $\begin{array}{l}\text { Angle of repose } \\
(\theta)( \pm S D)\end{array}$ & $\begin{array}{l}\text { Bulk density } \\
(\mathrm{g} / \mathrm{cc})( \pm \mathrm{SD})\end{array}$ & $\begin{array}{l}\text { Tapped density } \\
\text { (g/cc) }( \pm S D)\end{array}$ & $\begin{array}{l}\text { Carr's index }(\%) \\
( \pm \text { SD) }\end{array}$ & $\begin{array}{l}\text { Hausner's ratio } \\
( \pm S D)\end{array}$ \\
\hline F1 & $25.0 \pm 0.45$ & $0.88 \pm 0.021$ & $0.98 \pm 0.01$ & $12.54 \pm 0.42$ & $1.12 \pm 0.05$ \\
\hline $\mathrm{F} 2$ & $25.5 \pm 0.31$ & $0.87 \pm 0.098$ & $0.99 \pm 0.04$ & $11.49 \pm 0.53$ & $1.13 \pm 0.06$ \\
\hline F3 & $28.4 \pm 1.24$ & $0.85 \pm 0.047$ & $0.98 \pm 0.04$ & $13.31 \pm 0.78$ & $1.15 \pm 0.01$ \\
\hline $\mathrm{F} 4$ & $26.3 \pm 0.98$ & $0.86 \pm 0.047$ & $0.99 \pm 0.04$ & $12.50 \pm 0.44$ & $1.14 \pm 0.05$ \\
\hline F5 & $29.9 \pm 1.63$ & $0.78 \pm 0.06$ & $0.96 \pm 0.08$ & $16.66 \pm 0.79$ & $1.15 \pm 0.01$ \\
\hline
\end{tabular}
weight is considered to be within the specification and acceptable [19].

$$
\mathrm{F}(\%)=\frac{\text { Initial Weight }- \text { Final weight }}{\text { Initial weight }} 100
$$

Table 7: Pre-compression parameters of Ibuprofen granules

(S.D = Standard deviation), $\mathrm{n}=3$ 
Table 8: Post-compression parameters of bilayer tablets

\begin{tabular}{llcll}
\hline $\begin{array}{l}\text { Formulations } \\
\text { code }\end{array}$ & $\begin{array}{l}\text { Thickness } \\
(\mathbf{m m})^{*}\end{array}$ & $\begin{array}{l}\text { Hardness } \\
\left(\mathbf{K g} / \mathbf{c m}^{2}\right)^{*}\end{array}$ & $\begin{array}{l}\text { Friability } \\
(\mathbf{\%})^{*}\end{array}$ & $\begin{array}{l}\text { Weight } \\
\text { variation } \\
\text { (mg)** }\end{array}$ \\
\hline F1 & 6.5 & 6.8 & 0.59 & 950.33 \\
F2 & 6.6 & 6.12 & 0.52 & 1025.68 \\
F3 & 6.5 & 7.5 & 0.47 & 874.00 \\
F4 & 6.5 & 7.10 & 0.49 & 915.05 \\
F5 & 6.6 & 8.2 & 0.45 & 985.30 \\
\hline
\end{tabular}

*All values are mean, $\mathrm{n}=3$, **All values are mean, $\mathrm{n}=20$

Table 9: Disintegration time for Paracetamol IR layer assay of bilayer tablets

\begin{tabular}{ll}
\hline Formulation code & Disintegration time* \\
\hline F1 & $90-120 \mathrm{~s}$ \\
F2 & $4-6 \mathrm{~min}$ \\
F3 & $6-8 \mathrm{~min}$ \\
F4 & $8-10 \mathrm{~min}$ \\
F5 & $10-12 \mathrm{~min}$ \\
\hline$*(n=6)$ &
\end{tabular}

Table 10: Drug content in formulation F1

\begin{tabular}{lll}
\hline Formulation code & Paracetamol & Ibuprofen \\
\hline F1 & 97.90 & 97.64 \\
\hline
\end{tabular}

\section{Disintegration time}

A tablet was placed in each of the six tubes of the basket. Suspend the assembly in water maintained at a temperature of $37^{\circ} \mathrm{C} \pm 2^{\circ} \mathrm{C}$ and operate the apparatus, simultaneously note the time taken to disintegrate completely using stopwatch [20].

\section{Drug content: Assay: (BY HPLC)}

For Paracetamol and Ibuprofen

Procedure

Chromatographic system

Apparatus: HPLC

Column: $\mathrm{C} 8$

Wave length: $220 \mathrm{~nm}$

Injection volume: $5 \mu \mathrm{l}$

Flow rate: $1.5 \mathrm{ml} / \mathrm{min}$

Column temperature: $35^{\circ} \mathrm{C}$

Type of detector: UV

\section{Mobile phase preparation}

A mixture of 75 volumes of buffer solution prepared by dissolving $3.9 \mathrm{~g}$ of sodium dihydrogen phosphate dihydrate and $8.9 \mathrm{~g}$ disodium hydrogen phosphate dihydrate in water, adjust to $\mathrm{pH} 7.0$ with orthophosphoric acid, dilute to $1000 \mathrm{ml}$ with water and 24.5 volume of acetonitrile and 0.5 volume of methanol.

\section{Standard preparation}

Weigh accurately $325 \mathrm{mg}$ of Paracetamol into $50 \mathrm{ml}$ volumetric flask and make up the volume with media. Take $2 \mathrm{ml}$ from the above solution into 25 volumetric flasks and make up the volume with media.

Weigh accurately $400 \mathrm{mg}$ of Ibuprofen into $50 \mathrm{ml}$ volumetric flask and make up the volume with media. Take $2 \mathrm{ml}$ from the above solution into 25 volumetric flasks and make up the volume with media.

\section{Sample preparation}

One tablet was taken from F1 batch and crushed in pestle mortar. Crushed powdered will be taken into $50 \mathrm{ml}$ volumetric flask and make up the volume with media.
Table 11: In vitro dissolution profile of Bilayer tablets F-1

\begin{tabular}{llll}
\hline S. No. & Time intervals & \multicolumn{2}{c}{ Cumulative \% drug release } \\
\cline { 3 - 4 } & & Paracetamol & Ibuprofen \\
\hline 1. & $0 \mathrm{~min}$ & 0.00 & 0.00 \\
2. & $5 \mathrm{~min}$ & 37.85 & 0.53 \\
3. & $10 \mathrm{~min}$ & 72.05 & 2.36 \\
4. & $15 \mathrm{~min}$ & 88.64 & 5.42 \\
5. & $20 \mathrm{~min}$ & 94.20 & 8.37 \\
6. & $30 \mathrm{~min}$ & 96.15 & 13.56 \\
7. & $40 \mathrm{~min}$ & 97.87 & 19.34 \\
8. & $60 \mathrm{~min}$ & - & 21.56 \\
9. & $2 \mathrm{~h}$ & - & 33.75 \\
10. & $4 \mathrm{~h}$ & - & 52.40 \\
11. & $6 \mathrm{~h}$ & - & 71.02 \\
12. & $8 \mathrm{~h}$ & - & 81.31 \\
13. & $10 \mathrm{~h}$ & - & 92.20 \\
14. & $12 \mathrm{~h}$ & - & 97.65 \\
\hline
\end{tabular}

Table 12: Kinetics of IR drug release of formulation-1

\begin{tabular}{lll}
\hline Plot & $\mathbf{K}_{\mathbf{0}}$ & $\mathbf{R}^{\mathbf{2}}$ \\
\hline Zero-order & 0.327 & 0.669 \\
First-order & 0.00460 & 0.933 \\
Higuchi & 9.157 & 0.839 \\
Peppas & 1.8156 & 0.843 \\
\hline
\end{tabular}

Table 13: Kinetics of SR drug release of formulation-1

\begin{tabular}{lll}
\hline Plot & $\mathbf{K}_{\mathbf{0}}$ & $\mathbf{R}^{\mathbf{2}}$ \\
\hline Zero-order & 0.327 & 0.9540 \\
First-order & 0.00460 & 0.9572 \\
Higuchi & 9.157 & 0.994 \\
Peppas & 1.8156 & 0.9573 \\
\hline
\end{tabular}

Take $2 \mathrm{ml}$ from the above solution into 25 volumetric flasks and make up the volume with media.

Procedure

Inject $5 \mu \mathrm{L}$ portion of diluent as blank five replicate injections of standard preparation and one injection of each test preparation into the HPLC system record the chromatograms and measure the peaks response.

Calculation

$$
\begin{aligned}
& =\frac{\text { Samplearea }}{\text { Standardarea }}, \frac{\text { Standard weight }}{50}, \frac{250}{25}, \frac{25}{\text { Sampleweight }} \\
& \frac{\text { Averageweight }}{2}, \frac{\text { Potency }}{\text { Labelled claim }} \cdot 100
\end{aligned}
$$

In vitro dissolution studies

Procedure of dissolution of bilayer tablets

Six tablets of Paracetamol and Ibuprofen (Bilayer tablets) were introduced in the dissolution apparatus I.P Type I (paddle). The medium used was $900 \mathrm{ml}$ of phosphate buffer solution ( $\mathrm{pH}$ 5.8), and the dissolution medium was maintained at the temperature of $37.5 \pm 0.5^{\circ} \mathrm{C}$, the RPM was set at 50. The dissolution was carried out for $12 \mathrm{~h}$ and sample withdrawn at predetermined intervals. The estimation was carried out by HPLC method.

\section{For Paracetamol and Ibuprofen}

Procedure

Chromatographic system

Column: C8

Column temperature: $35^{\circ} \mathrm{C}$

Flow rate: $1.5 \mathrm{ml} / \mathrm{min}$ 


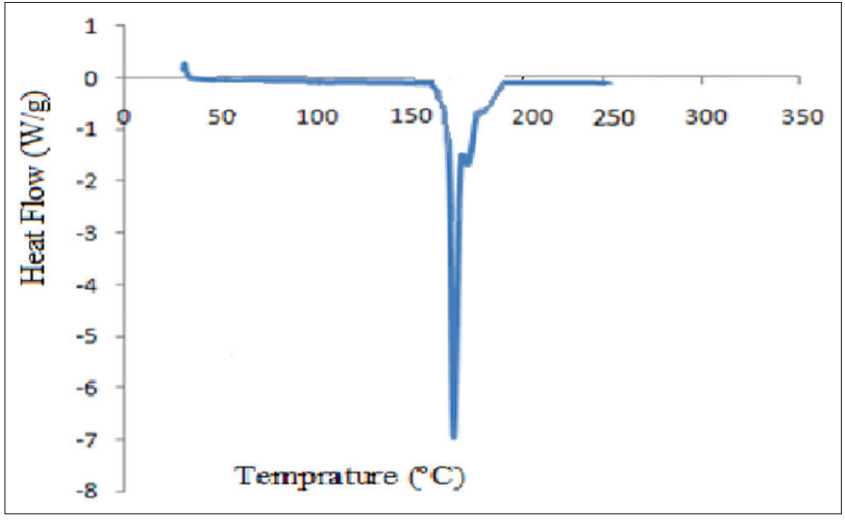

Fig. 1: Differential scanning calorimetry of Paracetamol

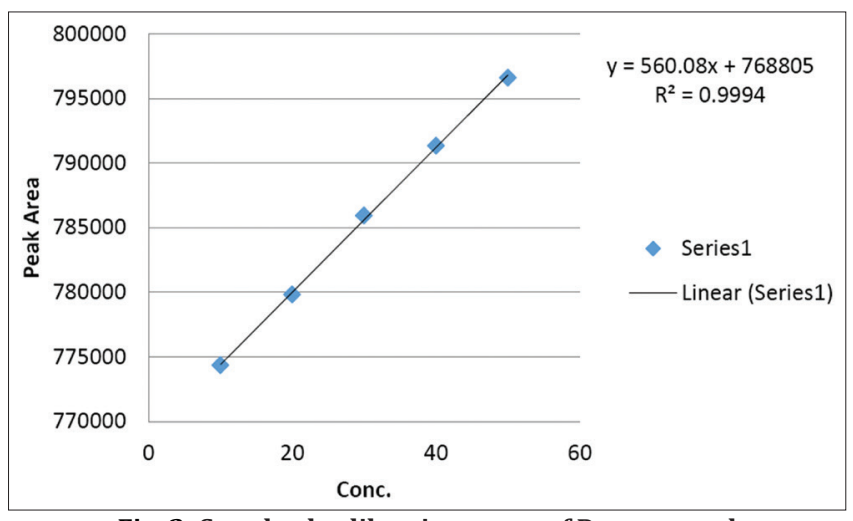

Fig. 2: Standard calibration curve of Paracetamol

Injection volume: $5 \mu \mathrm{l}$.

Detector Wavelength: $220 \mathrm{~nm}$

Run time: $14 \mathrm{~min}$

Type of detector: UV

\section{Dissolution media}

Dissolve $6.8 \mathrm{~g}$ of potassium dihydrogen phosphate in $1000 \mathrm{ml}$ of water and adjust the $\mathrm{pH}$ to 5.8 with $0.2 \mathrm{M}$ sodium hydroxide.

\section{Mobile phase preparation}

A mixture of 75 volumes of buffer solution prepared by dissolving $3.9 \mathrm{~g}$ of sodium dihydrogen phosphate dihydrate and $8.9 \mathrm{~g}$ disodium hydrogen phosphate dihydrate in water, adjust to $\mathrm{pH} 7.0$ with orthophosphoric acid, dilute to $1000 \mathrm{ml}$ with water, and 25 volume of acetonitrile.

\section{Standard preparation of Paracetamol}

Weigh accurately $28 \mathrm{mg}$ of Paracetamol and transfer into a $100 \mathrm{ml}$ volumetric flask, dissolve and dilute up to volume with dissolution media.

Take $1 \mathrm{ml}$ from the above solution and transfer into $10 \mathrm{ml}$ volumetric flask, dissolve and dilute up to volume with dissolution media.

\section{Standard preparation of Ibuprofen}

Weigh accurately $35 \mathrm{mg}$ of Ibuprofen and transfer into a $100 \mathrm{ml}$ volumetric flask, dissolve and dilute up to volume with dissolution media.

Take $1 \mathrm{ml}$ from the above solution and transfer into $10 \mathrm{ml}$ volumetric flask, dissolve and dilute up to volume with dissolution media.

\section{Sample preparation}

Take $2 \mathrm{ml}$ from the above solution and transfer into $25 \mathrm{ml}$ volumetric flask and volume make up with dissolution media.

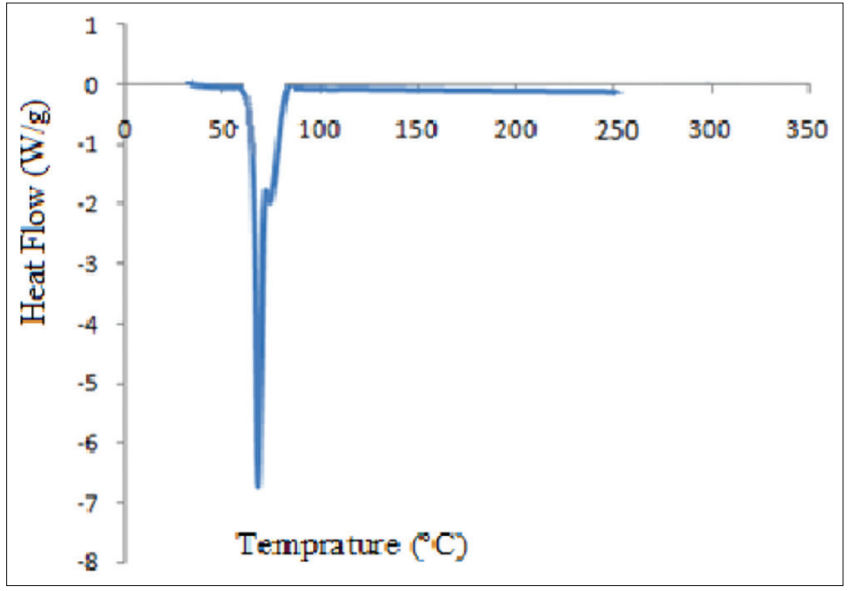

Fig. 3: Differential scanning calorimetry of Ibuprofen

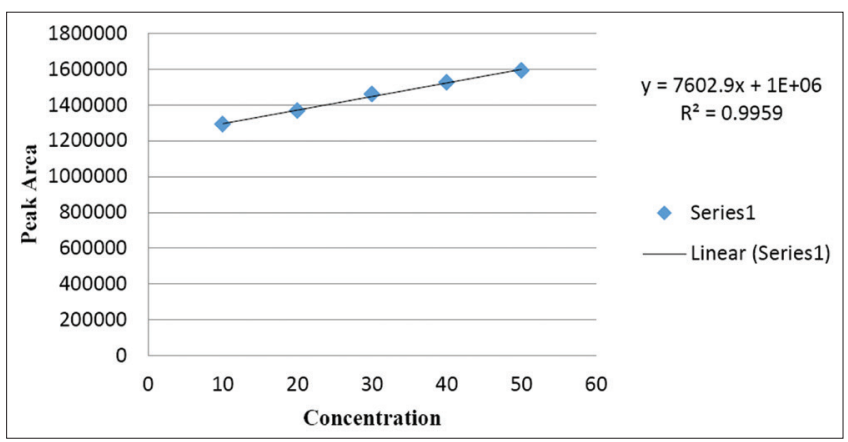

Fig. 4: Standard calibration curve of Ibuprofen

Procedure

Inject $5 \mu \mathrm{L}$ portion of diluent as blank, six replicate injections of standard preparation, and one injection of each test preparation into the HPLC system, record the chromatograms, and measure the peaks response [21].

Calculation

$$
\begin{aligned}
& =\frac{\text { Samplearea }}{\text { Standardarea }} \cdot \frac{\text { Standard weight }}{100} \cdot \frac{1}{10} \\
& \frac{900}{\text { Lablled claim }} \cdot \frac{25}{2}, \frac{\text { Potency }}{100} \cdot 100
\end{aligned}
$$

\section{Drug release kinetics}

The release kinetics was studied by various kinetic models such as zero-order plot, first-order plot, Higuchi plot, and Korsmeyer-Peppas plot. To study the release kinetics of the nanoparticle gel data obtained from in vitro drug release studies was plotted in various kinetic models: Zero-order as cumulative amount of drug releases versus time, firstorder as long cumulative \% of drug remaining versus time, Higuchi model as cumulative $\%$ of drug released versus square root of time, and Korsmeyer-Peppas model as log cumulative \% drug release versus long time. The best fit model was confirmed by the value of correlation coefficient near to one [22].

\section{RESULTS AND DISCUSSION}

\section{Paracetamol}

Solubility

Paracetamol was found to be soluble in methanol, ethanol, acetone, 0.1 $\mathrm{N}$ HCL, and sparingly soluble in water.

\section{Melting point}

DSC curve of Paracetamol showed a sharp endothermic peak near $169^{\circ} \mathrm{C}$ that is indicative of its melting temperature. 


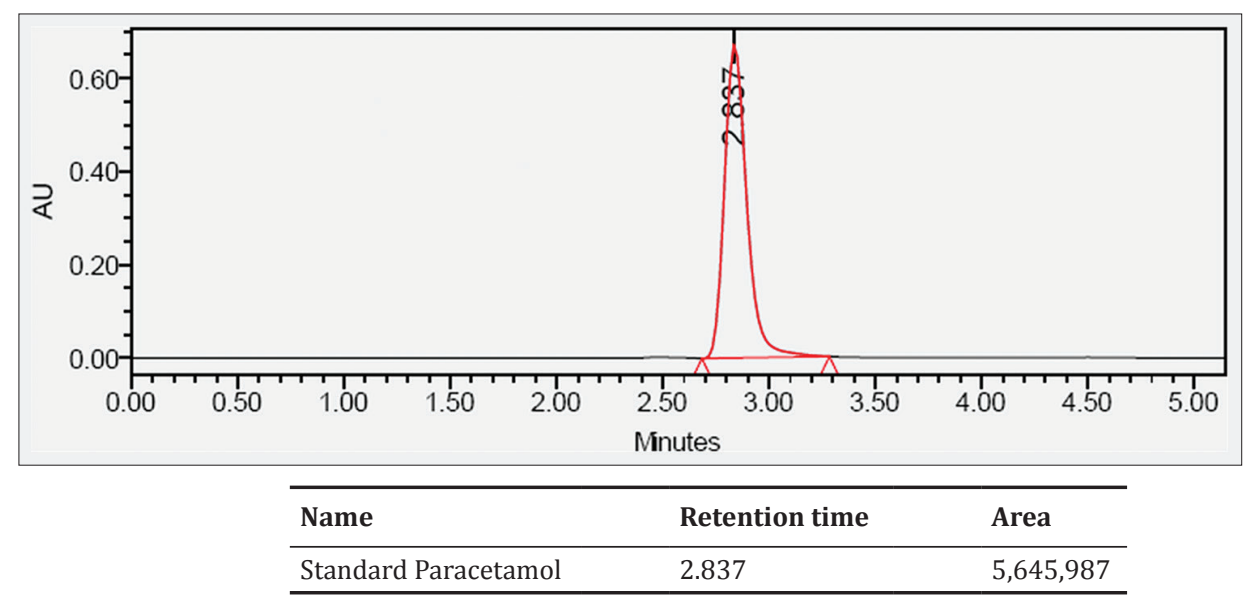

Fig. 5: Paracetamol assay standard chromatogram

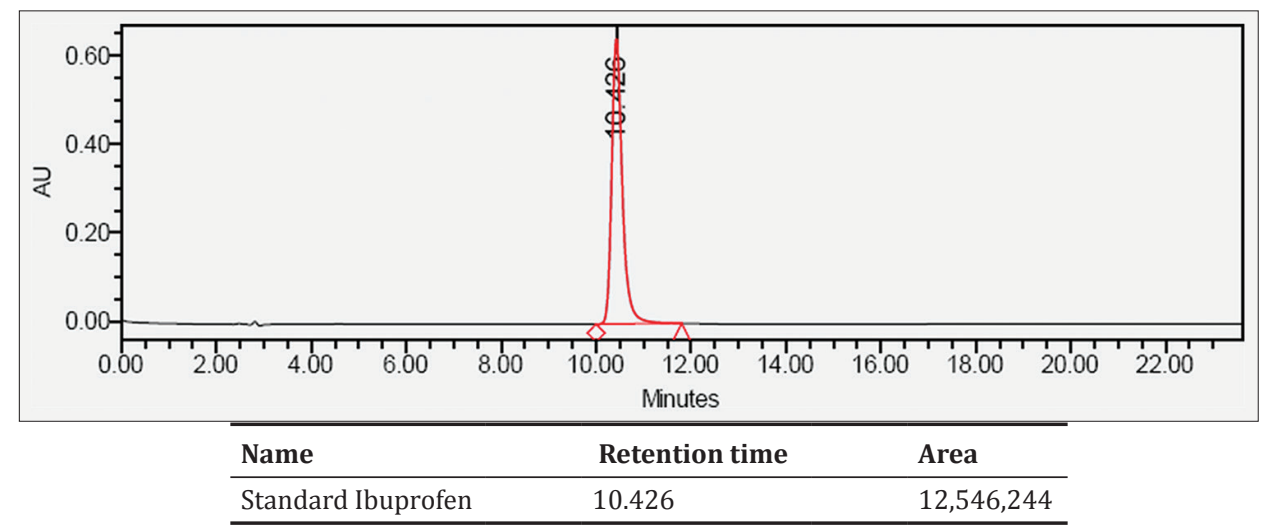

Fig. 6: Ibuprofen assay standard chromatogram

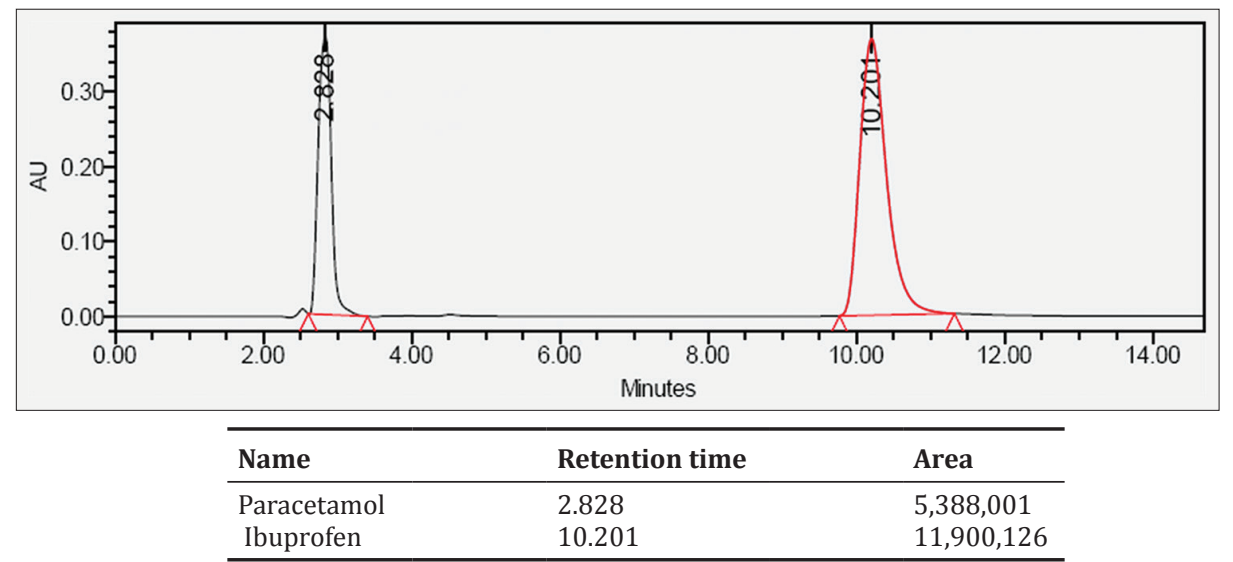

Fig. 7: Assay sample of formulation F1

\section{FTIR analysis}

FTIR spectroscopic analysis was carried out to characterize drug. The FTIR spectra obtained were compared with that given in pharmacopeia for Paracetamol. Diagnostic peaks and fingerprint regions were found identical. These characteristics peaks are useful in identification of drug. The results obtained showed that there are no interactions between the components when taken together.

\section{Linearity by HPLC method}

- Standard stock solution of Paracetamol

Accurately weighed $100 \mathrm{mg}$ Paracetamol and dissolved in $100 \mathrm{ml}$ of the mobile phase. $1 \mathrm{ml}$ pipette out from above solution and taken in $10 \mathrm{ml}$ volumetric flask and volume was makeup with mobile phase. A standard stock solution contains $100 \mu \mathrm{g} / \mathrm{ml}$.
Standard graph of Paracetamol: Form this standard stock solution, a series of dilution $(10,20,30,40$, and $50 \mu \mathrm{g} / \mathrm{ml})$ were prepared using mobile phase.

\section{Evaluation of Paracetamol blended granules}

The blended granules of different formulation were evaluated for angle of repose, bulk density, tapped density, Carr's index, and Hausner's ratio. The results of these evaluations were as follows:

\section{Angle of repose}

Angle of repose for the granules of F1-F5 was found to be 25.1-28.6, which indicates good flow property.

\section{Carr's index}


The Carr's index for the granules of F1-F5 was found to be 14.58-15.34\%, which shows good flowing properties.

\section{Hausner's ratio}

Hausner ratio was found to be 1.12-1.15, it indicates good flow properties of the granules.

\section{Ibuprofen}

Solubility

Ibuprofen was found to be freely soluble in methanol, ethanol, acetone, soluble in PBS of pH 6.8, 7.4, practically insoluble in water, and 0.1 N HCL.

\section{Melting point}

Melting point of the pure Ibuprofen was found to be $76^{\circ} \mathrm{C}$ which was within the limit as per the IP 2018. DSC curve of Ibuprofen exhibits endothermic peak at $76^{\circ} \mathrm{C}$.

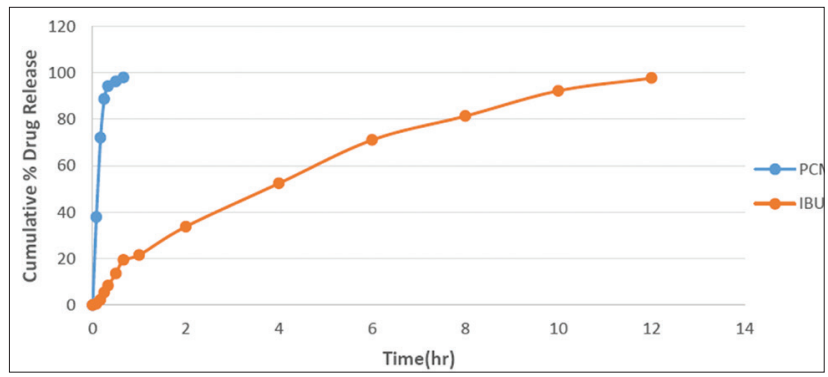

Fig. 8: In vitro dissolution profile of formulation F-1

\section{Linearity by HPLC method}

- Standard stock solution of Ibuprofen

Accurately weighed $100 \mathrm{mg}$ Ibuprofen and dissolved in $100 \mathrm{ml}$ of mobile phase. $1 \mathrm{ml}$ pipette out from above solution and taken in $10 \mathrm{ml}$ volumetric flask and volume was make up with mobile phase. A standard stock solution contains $100 \mu \mathrm{g} / \mathrm{ml}$.

Standard graph of Ibuprofen: RM this standard stock solution, a series of dilution $(10,20,30,40$, and $50 \mu \mathrm{g} / \mathrm{ml})$ were prepared using mobile phase.

\section{Evaluation of Ibuprofen blended granules}

The blended granules of different formulation were evaluated for angle of repose, bulk density, tapped density, Carr's index, and Hausner's ratio. The results of these evaluations were as follows:

\section{Angle of repose}

Angle of repose for the granules of F1-F5 was found to be 25.0-39.9, which indicates good flow property.

\section{Carr's index}

The Carr's index for the granules of F1-F5 was found to be 11.49-16.66\%, which shows good flowing properties.

\section{Hausner's ratio}

Hausner ratio was found to be 1.12-1.15; it indicates good flow properties of the granules.

\section{Post-compression parameters}

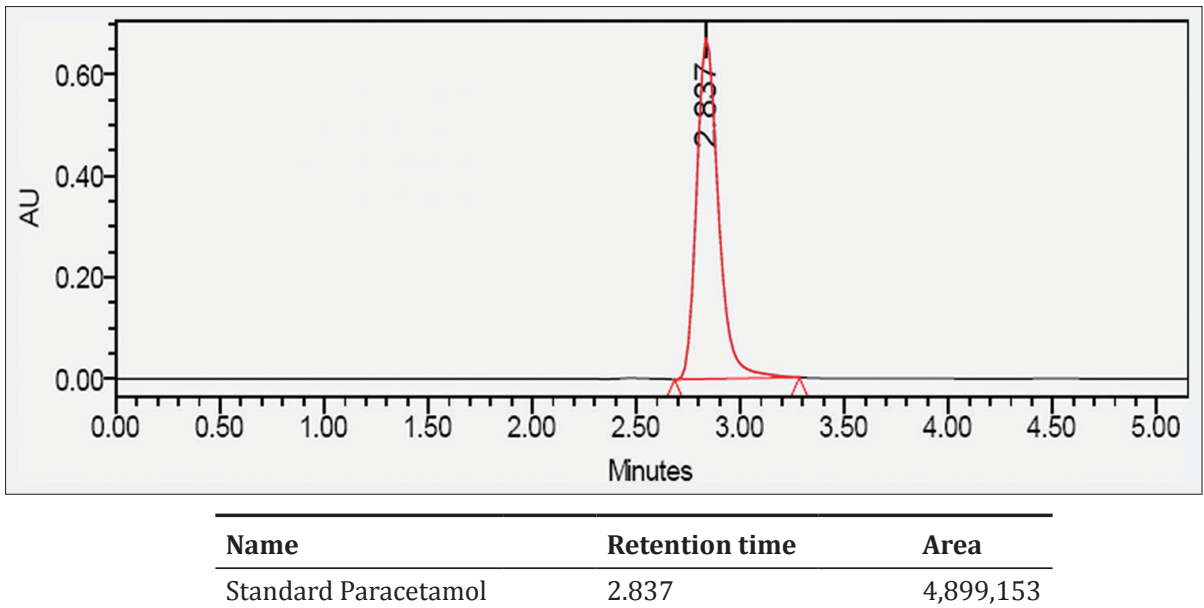

Fig. 9: Dissolution standard of Paracetamol

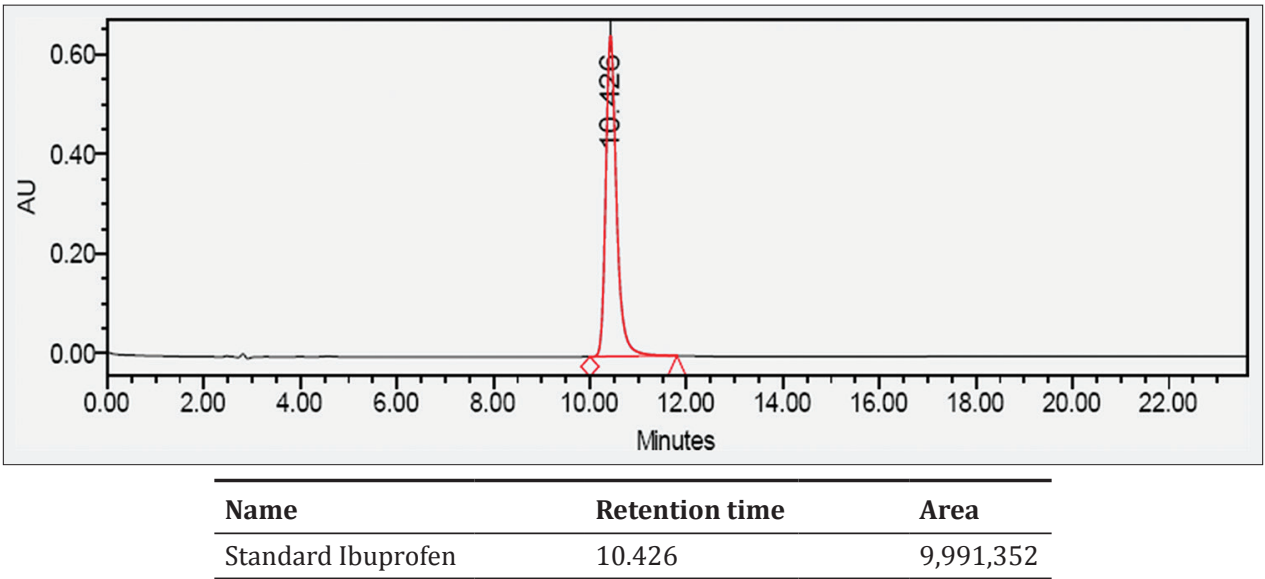

Fig. 10: Dissolution standard of Ibuprofen 

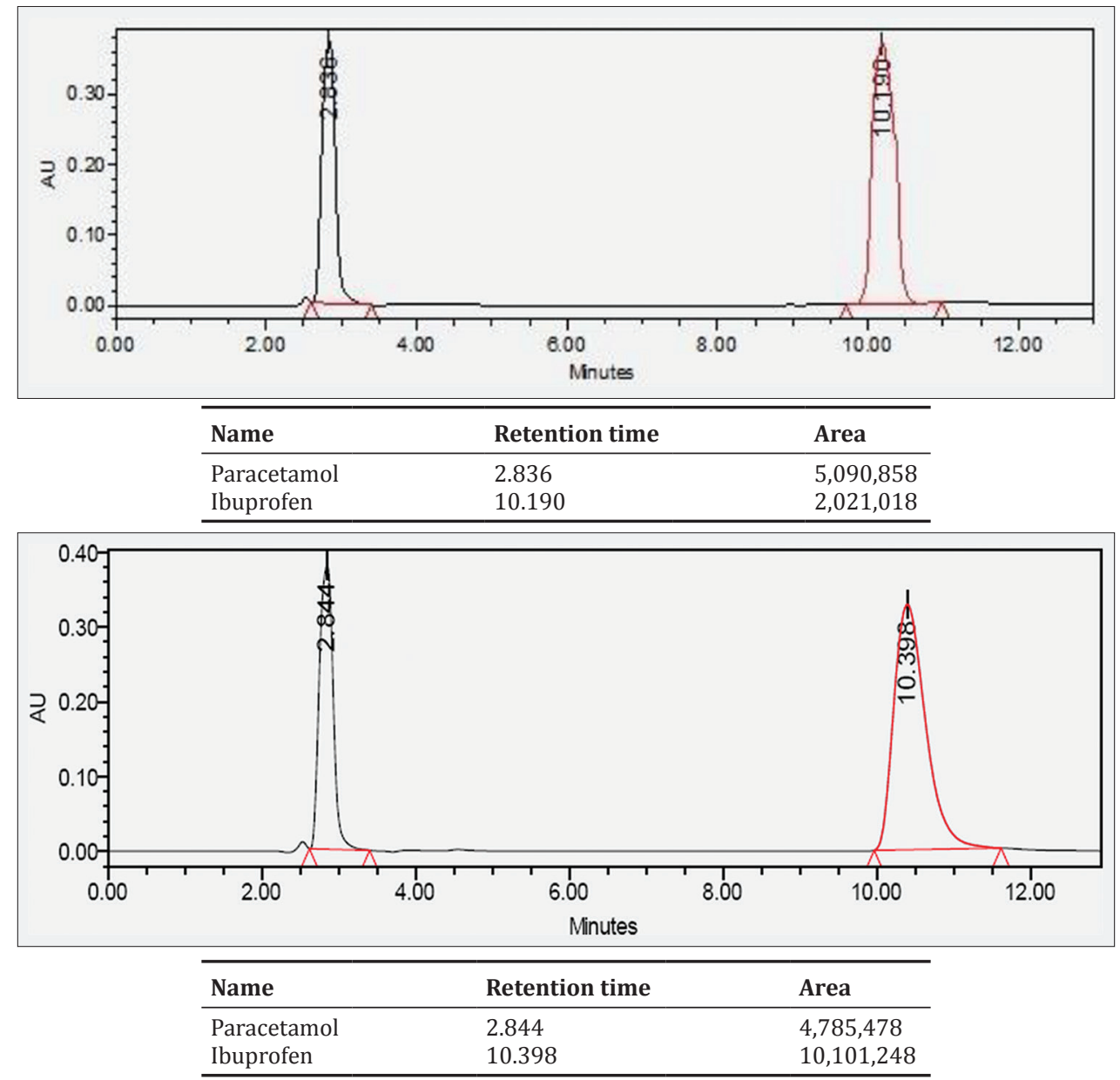

Fig. 11: Dissolution sample of formulation F1

Disintegration test for paracetamol IR Layer

\section{Model chromatograms}

\section{In vitro dissolution studies}

\section{Model chromatograms}

Dissolution

\section{Kinetic study for Paracetamol IR layer of bi-layer tablet}

The data obtained for in vitro release were fitted into equations for zero-order, first-order, Higuchi, and Korsmeyer-Peppas release models. The interpretation of data was based on the value of the resulting regression coefficients.

From these values, it was observed that the first-order model was found to be best suited with $\mathrm{R}^{2}$ value of 0.933 .

\section{Kinetic study for Ibuprofen SR layer of bilayer tablet}

The data obtained for in vitro release were fitted into equations for zeroorder, first-order, Higuchi, and Korsmeyer-Peppas release models. The interpretation of data was based on the value of the resulting regression coefficients.

From these values, it was observed that the Higuchi model was found to be best suited with $R^{2}$ value of 0.994 .

\section{DISCUSSION}

Paracetamol is also known as acetaminophen, centrally acting analgesic derivative of p-aminophenol. Commonly used for its antipyretic and analgesic effects, which has a biological half-life of 1-4 h. Ibuprofen is described as 2-(4-isobutylphenyl)propionic acid and is a nonsteroidal compound, which exhibits high levels of anti-inflammatory, analgesic, and antipyretic activities necessary for the effective treatment of rheumatoid arthritis and osteoarthritis. The biological half-life of Ibuprofen is 2-4 h. This drug works by blocking the enzyme in your body that makes prostaglandins. Decreasing prostaglandins help to reduce pain, swelling, and fever. In the present work, an attempt was made to prepare bilayer tablets of Paracetamol (IR) and Ibuprofen (SR) with excipients such as MCC, starch, PVP K-30, sodium starch glycolate, hydroxyl propyl methylcellulose E50LV, ethylcellulose, magnesium stearate, talc, and isopropyl alcohol. Prepared bilayered tablets were evaluated for hardness, friability, weight variation, drug content uniformity, drug-excipient interaction, and in vitro drug release, and stability studies. Among the various formulations prepared, Formulation F1 with SSG for Paracetamol release and HPMC E50LV for Ibuprofen release showed comparatively good release, which complies with the dissolution requirements.

\section{CONCLUSION}

In the present work, an attempt was made to design a combination of bi-layer tablets containing Paracetamol immediate-release layer and Ibuprofen sustained release layer. FT-IR studies reveal that there were no significant interactions between both the drugs and between the drugs and their respective excipients. For achieving immediately release of Paracetamol, polymer-like Sodium starch glycolate was used. For sustained release of Ibuprofen, polymers like HPMC E50LV were used. Here, F1 was 
best formulation among them. Paracetamol release $97.87 \%$ after $40 \mathrm{~min}$. Formulation F1 gave $97.65 \%$ drug release after $12 \mathrm{~h}$. Therefore, F1 was selected as best formulation among F1-F5. The bi-layer tablets prepared formulated F1 shown good post-compression parameters such as hardness, and friability weight variation drug content which were within the limits. Both the drugs in bi-layer tablets are shown dissolution profiles within the limit. Since, HPMC E50LV is a good sustained release polymer. The combination of HPMC E50LV and CMC gave good sustained drug release for $12 \mathrm{~h}$. From this study by preparing bilayer tablets, it was concluded that we could reduce the dosage frequency, dose-related side effects, and improve the bioavailability of drugs which in turn improves patient compliance. Thus, a fixed-dose combination tablet of Paracetamol and Ibuprofen were designed as bi-layer tablets which will have good patient compliance.

\section{ACKNOWLEDGMENT}

The author would like to thanks Dr. Dinesh Kaushik for providing a platform and facility to conduct research work. The authors would like to thanks Comboitic Global Pvt. Ltd. for providing a gift sample of Ibuprofen and Paracetamol.

\section{AUTHORS' CONTRIBUTIONS}

All the authors have contributed equally.

\section{CONFLICTS OF INTEREST}

The authors declare that they have no conflicts of interest.

\section{STRUCTURAL ABSTRACT}
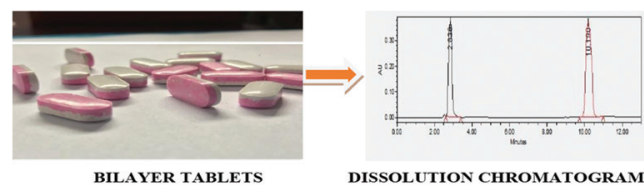

DISSOLUTION CHROMATOGRAM

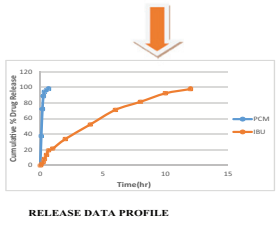

\section{REFERENCES}

1. Khaleel S, Patil P, Bhagat M. Bilayer tablet an emerging trend. Eur J Pharm Med Res 2017:4:471-80.

2. Gopinath C, Hima V. An overview on bilayered tablet technology. J Glob Trends Pharm Sci 2013;4:1085-98.

3. Verma R, Kishor D. Bi-layer tablets for various drugs. Sch Acad J
Pharm 2014;3:271-9.

4. Bhatia E, Vaishy P, Mishra A, Pathak A. Bilayered tablet technology. Int J Pharm Biol Arch 2014;5:9-18.

5. Devtalu S, Patil A, Bari M. A review on novel approach bilayer tablet technology. Int J Pharm Sci Rev Res 2013;21:46-52.

6. Reddy P, Rao D, Kumar R. Bi-layer technology an emerging trend: A review. Int J Res Dev Pharm Life Sci 2013;2:404-11.

7. Trpathi KD. Essentials of Medical Pharmacology. $6^{\text {th }}$ ed. New Delhi: Jaypee Brothers; 2003. p. 193, 198-9.

8. Shirse P. Formulation and evaluation of bilayer tablets of diclofrenac sodium with ranitidine HCL for sustained and immediate release. J Appl Pharm Sci 2012;2:136-41.

9. Payghan S, Disuza J. Formulation, evaluation and development of bilayer tablet. Int J Pharm Res Dev 2011;3:80-7.

10. Darekar A, Jadhav S, Saudager R. Bilayer tablet technology: An overview. Int J ChemTech Res 2017;10:595-603.

11. Zhu C, Xu S, Han X, Wang W, He W, Yin L, et al. Sustained release bilayer tablet of ibuprofen and phenylephrine hydrochloride: Preparation and pharmacokinetics in beagle dogs. AAPS PharmSciTech 2019;20:86.

12. Sarangi MK, Chowdary K, Sundriyal A. Formulation development and evaluation of bilayer tablets containing paracetamol sr and tizanidine. J Appl Pharm 2014;6:347-59.

13. Sudhakar M, Rao V, Samalla N. Development and optimization of paracetamol immediate release and aceclofenac controlled release bilayer tablets. Am J Adv Drug Deliv 2013;1:93-101.

14. Yasmeen Z, Mamatha T, Farheen H. Dissolution method development and validation for combination of ibuprofen and paracetamol tablets. Asian J Pharm| Clin Res 2013;6:162-6.

15. Payghan S, Disuza J. Formulation, evaluation and development of bilayer tablet. Int J Pharm Res Dev 2011;3:80-7.

16. Islam SA, Banu H, Mostafa R. Bilayer tablets of paracetamol and aceclofenac: formulation and evaluation. Int $\mathrm{J}$ Pharm Technol 2011;17:811-22.

17. Hosna B, Sahariar M, Shahdaat M. Formulation development of bilayer acetaminophen tablets for extended drug release. J Chem Pharm Res 2011;3:348-60.

18. Biljana G, Rade I. Formulation and evaluation of immediate release tablets with different types of paracetamol powders prepared by direct compression. Afr J Pharm Pharmacol 2011;5:31-41.

19. Rahman M, Roy S. Evaluation of various grades of hydroxypropylmethylcellulose matrix systems as oral sustained release drug delivery systems. J Pharm Sci Res 2011;3:930-8.

20. Shiyani B, Gattani S, Surana S. Formulation and evaluation of bilayer tablet of metoclopramide hydrochloride and ibuprofen. AAPS PharmSciTech 2008;9:818-27.

21. Indian Pharmacopoeia. Government of India, Ministry of health and family welfare. Ghaziabad: Published by The Indian Pharmacopoeia Commission; 2018. p. 1217-8, 1514-7.

22. Saiesh P, Shabaraya AR, Shripathy D. Kinetic modelling of drug release. Int J Univ Pharm Biosci 2014;3:92-104. 